\title{
NERINT/UFRGS: 20 YEARS ANALYSING INTERNATIONAL RELATIONS
}

\author{
Paulo Fagundes Visentini ${ }^{1}$ \\ Guilherme Thudium²
}

The Brazilian Centre for Strategy and International Relations (NERINT) of the Universidade Federal do Rio Grande do Sul (UFRGS) ${ }^{3}$, created in I999, was the first centre focused exclusively on the study and research in International Relations in Southern Brazil. It was founded by Professors Paulo Fagundes Visentini and Luiz Dario Ribeiro (Department of History), Alvaro Luiz Heidrich (Department of Geography), Carlos Schmidt Arturi (Department of Political Science), Juan Algorta Plá (Department of Economics) and, shortly after, Marco Cepik (Department of Political Science) joined the group of researchers. Soon, the centre became a Research Group of the National Council for Scientific and Technological Development (CNPq), a federal organisation linked to the Ministry of Science and Technology focused on supporting and promoting research in Brazil. NERINT was initially established within the Latin American Institute for Advanced Studies (ILEA/UFRGS), where it remained for I6 years as a multidisciplinary study centre. Its main objective is to promote teaching, research and extension projects, as well as to develop an editorial program capable of filling the national bibliographic gap in the area of International Relations. After a brief period at the university's Department of Economics and International Relations, NERINT joined the Centre for International Studies on Government (CEGOV), a multidisciplinary research body subordinated to the Dean's Office at UFRGS and dedicat-

I Full professor of International Relations at the Universidade Federal do Rio Grande do Sul (UFRGS). Founder and Coordinator of the Brazilian Centre for Strategy \& International Relations (NERINT) and Editor-in-Chief of Austral: Brazilian Journal of Strategy \& International Relations. E-mail: paulovi.ufrgs@gmail.com.

2 Master in Political Science and PhD Student in Strategic and International Studies at UFRGS. Researcher at NERINT and Assistant Editor at Austral: Brazilian Journal of Strategy Q International Relations. E-mail: guilherme.thudium@ufrgs.br.

3 Federal University of Rio Grande do Sul (UFRGS), in English. In 2018, the Brazilian Ministry of Education ranked UFRGS as the best federal university in the country. 
ed to public policies in the international area.

From its inception, NERINT has remained a rigorously academic and public research centre with no ties to governments, political movements or private institutions and foundations. This, however, did not inhibit the establishment of partnerships for events and other initiatives, such as research and publications, always respecting academic and institutional freedom. Yet, independence does not mean a lack of commitment to our nation and society. The primary focus has always been to contribute to national development with knowledge and analysis of the strategic options for Brazil's international insertion in a changing world. Moreover, the idea of creating a locus to unite individual efforts in the study of International Relations in the Southern region converged with the further development of the area, which occurred a decade ago. The academic inauguration of International Relations in Brazil, in the late I980s, however, was marked by a globalist world-view to the detriment of a national project. Thus, it was necessary to rescue the threatened Brazilian diplomatic traditions, predominantly guided by the pursuit of autonomy and national development. In this sense, I999 proved to be a critical year, with the crisis of the Real and the liberal outlook of international projection. And in 200 I the terrorist attacks of September II would fundamentally change the international landscape.

\section{Research axes}

NERINT is dedicated to the analysis of topics ranging from Brazilian Foreign Policy in a comparative perspective to the problems of International Security, through the challenges of diplomacy, regional integration, the world-system analysis and national development. The work carried out by NERINT's researchers, with the support of graduate and undergraduate students, aims to monitor and analyse the main power poles of the international system. The emphasis of the empirical research has a special interest in three regions of the Geopolitical South: South America, Africa and Asia. In this sense, NERINT is characterised by research in the diplomatic, economic and security fields of the countries that make up the South-South axis of contemporary International Relations.

Exploratory studies carried out by NERINT on new developing countries have seen remarkable expansion since the early 2 Ist century. Cooperation with state, business, academic and social institutions has been intensified, as well as the direct contact with other centres in Latin America, Africa and Asia, in addition to the existing ones in Europe and North America. Throughout the years, there were different predominant research axes. Currently, the three 
main research lines developed within the scope of NERINT have prioritised a Grand Strategy for Brazil in the 2ist Century, the International Relations of the Asian Continent, and the Crises and Transformations of the World System. The objective of the former is to combine efforts in various spheres of society to guarantee sovereignty, security and national development, granting greater autonomy to Brazil in the international system. Thus, key themes for the Brazilian strategic insertion are analysed, such as the Brazilian Foreign and Defence Policy; the South American Strategic Environment; and the international relations of South-South cooperation.

It is within this framework that close collaborations have been developed with scholars in the areas of Diplomacy, Defence and International Security, as well as cooperation with the Ministry of Foreign Relations, the Ministry of Defence and academic partnerships in Brazil and abroad. Partnerships were also formed with the Armed Forces through academic cooperation agreements with the Centre for Strategic Studies of the Southern Military Command (NEE/CMS), as well as joint initiatives with institutions such as the Brazilian Army Command and General Staff School (ECEME) and the Superior School of War (ESG).

The second line of research addresses the main dynamics of international politics and security prevailing in the Asian continent, emphasising the regional balance of power, the interaction between different areas of the continent, its role in the global geopolitical chessboard and the relations between great powers. Specifically, this research agenda tries to analyse the Asian continent by studying four macro-regions: Middle East and Central Asia; the Indian subcontinent and the Indian Ocean; Russia and its surroundings; East Asia and the Pacific. Finally, the third line of research is devoted to the theoretical, historical and strategic study of the World System, focusing on the alternation between hegemonic cycles and crises and the analysis of this process as an element of transformation of the system itself, with special emphasis on the post-Cold War era. It also seeks to identify possible disruptions within the system itself and Brazil's growing role in it.

Thus, the advanced researches developed by NERINT sought to recover the historical dimension of international relations, which is traditionally neglected in the analyses of contemporary International Relations and Security and Defence Studies. Such redemption is also a theoretical concern, since International Relations, as well as defence issues, as areas dominated by the fields of Political Science, have been marked by instrumental theorisations.

In short, NERINT's main objective has always been the critical and innovative study of the systemic transformations of international relations. At the same time, it has sought to contribute to the discussion of a national 
project for Brazil by analysing the strategic options for the autonomous international insertion of the country, from the perspective of emerging states. Carrying out research activities differentiated from mainstream approaches in International Relations has allowed for links to be established with institutions and researchers from all continents, some of which have become associate researchers. Internationalisation took place through academic missions to various foreign institutions and, as well as inviting researchers from other nations who came to Porto Alegre, the Brazilian city that became an international hub in the beginning of the 2Ist century.

\section{Support for teaching and research activities}

From its early days, NERINT promoted formative extension courses to address the lack of undergraduate and graduate courses in International Relations in Southern Brazil, activities that, due to their pioneering spirit, were extremely successful. Within a framework of increased importance of international relations in the Brazilian political and economic agenda, NERINT acted as the main academic catalyst for the implementation, within the university, of a Master's program in International Relations in 2002, supported by the San Tiago Dantas Program and the Coordination for the Improvement of Higher Education Personnel (CAPES), and, consequently, of an undergraduate course in International Relations, in 2004. Finally, a Doctoral Program in Strategic and International Studies (PPGEEI) was created in 2010.

NERINT researchers constituted the core of all these initiatives, as well as contributed with the necessary elements to their academic projects. Similarly, undergraduate and graduate students of these new programs were granted a space to develop research and participate in institutional projects. It is also important to highlight that teachers and students took part in exchange programs from Argentina to China thanks to the activities of the centre. Likewise, NERINT welcomed African, Latin American and European students who conducted their own researches at UFRGS, in Porto Alegre.

From the moment graduate and undergraduate courses were implemented, extension activities were no longer formative and generalist, but focused on deepening specific innovative themes. A phase of major seminars had begun, usually through partnerships with institutions such as the Alexandre de Gusmão Foundation (FUNAG) of the Ministry of Foreign Affairs, the Konrad Adenauer Foundation, the Ministry of Defence, the South American Institute for Policy and Strategy (ISAPE), Renmin University (Beijing), Leiden University (Netherlands), the Higher Institute of International Relations (Mozambique), foreign embassies in Brazil, public and private universities, 
among others. NERINT has also participated in inter-institutional project networks such as "Pró-Defesa" and "Pró-Estratégia", joint initiatives of the Ministry of Defence and CAPES. One of these particular initiatives that is worth mentioning is the Brazilian Seminar of International Strategic Studies (SEBREEI), which was firstly held in 2012 and 20I3, in collaboration with PPGEEI. As of 20I6, SEBREEI formed a partnership with the Seminar of the Southern Military Command and the Union Houses Seminar, comprising in this association the Seminars of Strategic Studies, which took place simultaneously in both 2016 and 2018 .

The themes of these events were varied and aimed at different audiences. Among them, we can list: Diplomacy and Academy; South Africa; European Union; India; Integration Processes in South America; Brazilian Foreign Policy; India, Brazil and South Africa Dialogue Forum (IBSA); Eurasia; Migrations and Refugees; World System Transformations; Arab Spring; Middle Eastern Geopolitics; Northeast Asian Geopolitics; Russia and Central Asia; International Security and Defence; Brazilian Defence; Conflict and Development in Africa; Emerging Powers in Africa; BRICS; China's International Projection; and History of International Relations, among others.

\section{Editorial activity}

One of the areas where NERINT's contribution proved most remarkable was through the publication of books and international journals (see list in annex). NERINT has published two book collections: first, the International Relations and Integration Series, which aimed to publish original titles. Between I998 and 2008, through UFRGS' university press, ten books were published, some of which became emblematic of the International Relations historiography in Brazil. The International Studies Series, on the other hand, aimed to disseminate theses, dissertations and seminar materials that were innovative, but aimed at experts. Between 2003 and 2009, twelve works were edited in a partnership between NERINT and UFRGS's university press, with support from the San Tiago Dantas Program.

Since 20I3, NERINT publishes the Strategy, Defence and International Relations Series, successor to the previous two, through which six works have been published. NERINT's editorial policy has always prioritised academic independence over a commercial agenda. However, the crisis of academic publishers meant that the new series had to be produced in partnership with private publishers - first, Leitura XXI, and then Livraria Palmarinca - as a way of improving research circulation. Two of the publications had the support of renowned institutions such as the Meira Mattos Institute/ECEME 
and the Superior School of War/ESG. There are titles that address absolutely original themes in Brazil, such as Revolutions and International Relations and Defence Diplomacy. Furthermore, an interesting element among the three series is the strong representation of high-ranking Brazilian diplomats.

As for academic journals, two periodic publications were also created: the bilingual and semi-annual AUSTRAL: Brazilian Journal of Strategy and International Relations, edited by NERINT since 20I2, and the quarterly Conjuntura Austral, edited by PPGEEI since 20II. Published in print and digital formats, AUSTRAL (a reference to the South in Western linguistics), was the first Brazilian journal in the area of International Relations to be published entirely in English, in bilingual editions in Portuguese or Spanish - the official languages of Mercosur. AUSTRAL has published articles by Brazilian scholars and internationalists from all continents, focusing on the themes that make up the South-South axis of international relations. Its Editorial Board is composed of renowned academics from Brazil, South Africa, China, the United States, Argentina, India, France, Russia, Cameroon, Turkey, Cuba, Tunisia, Canada, the Netherlands and Australia. AUSTRAL has a large international circulation and is registered in major global indexers, such as Scopus Elsevier and Google Scholar, among others. The list of authors speaks for itself, demonstrating the great international insertion of the journal. In 20I6, NERINT also began to offer a digital and bilingual Research Bulletin, published by its Research Assistants.

\section{From CESUL to CEBRAFRICA}

NERINT was also the birthplace of African studies in the area of International Relations at UFRGS. In 2005, an agreement was signed by the Centre with the Alexandre de Gusmão Foundation (FUNAG), a public foundation linked to the Ministry of Foreign Affairs (Itamaraty), for the creation of the Center of Studies Brazil-South Africa (CESUL). Its purpose was to foster studies, events, exchanges and publications about a strategic nation for Brazil's foreign policy. In addition to those initiatives, the South African Series was created, which published five books (see list in annex). This program has formed a cluster to African and Africanist students, as well as promoted significant teaching exchanges. The success was such that, in 20II, CESUL gave rise to the Brazilian Center for African Studies (CEBRAFRICA), which initially conducted its activities as a research line within NERINT. The demand for African studies grew further and CEBRAFRICA, under the dynamic coordination of Professor Analúcia Danilevicz Pereira, also a researcher at NERINT, became a parallel and independent academic research centre at UFRGS. 
CEBRAFRICA brings together researchers from UFRGS and national and international institutions, as well as undergraduate and graduate students who conduct their research in the following lines: South-South Cooperation and the African Continent; Development, Security and Regional Integration; and Foreign Policy of African Countries. The South African Series has been transformed into an African Series to cover other countries of that continent. Since 20I2, it has published six exclusive works. In addition to the African Series, CEBRAFRICA has been publishing, since 20I6, the Brazilian Journal of African Studies (RBEA), every six months in print and digital versions in a bilingual English-Portuguese or Spanish format. The publication's international success attracted large numbers of African authors, serving as a link between Brazil and Africa. CEBRAFRICA is partnered with reputable institutions from Brazil, Argentina, Cuba, Mexico, Canada, South Africa, Angola, Mozambique, Senegal, Cape Verde, Egypt, Nigeria, Morocco, Portugal, United Kingdom, Netherlands, Sweden, Russia, India and China.

\section{0 years on}

Our philosophy aims to avoid competition between research centres and programs, seeking specialisation and complementarity. Thus, we were able to advance and consolidate a research agenda in limitedly studied areas and regions, always cooperatively. There is still room for everyone. Similarly, we've never prioritised following the changing criteria of academic agencies, which make many centres lose their identity and compete with one another. Another important point is teamwork: NERINT is the result of a group and collective action. The dedication of professors, but especially of students, was the main factor that made so many of these achievements possible. It would be impossible to mention all the academics who passed through the Centre. But we would like to mention a couple from the first and latest generations. Rafael Balardim and Kamilla Rizzi, history students and today university professors of International Relations, were vital during NERINT's early days. More recently, Maria Gabriela Vieira and Eduardo Secchi, undergraduate students of International Relations, have helped sustain today's complex activities. All this within a team of colleagues, organised in internal study groups in which relevant but little known works are discussed.

When it was founded, in I999, the main trend in international relations was neoliberal globalisation, which the founding researchers considered a threat to the National Project that had been in place since the Vargas Era. Always highlighting, however, that the post-Cold War world system did not represent an American phase of solitary hegemony, but rather an unstable phase 
of transition and struggle towards a "New Order". Two decades later, to the shock of many pundits and analysts, globalisation is now being questioned by the Trump administration and many other governments, including Brazil. Halfway through, in 2009, the BRIC(S) grouping emerged, signalling the overwhelming rise of China and the resurgence of Russia, countries which now suffer strong economic and political-military containment, respectively. All this only confirmed our initial prediction about the fragility and uncertainty of the international relations system in the post-bipolar world.

In I999, the second term of President Fernando Henrique Cardoso had only just started, and with that the first crisis of the new "strong and stable” Brazilian currency, the Real, which suffered a sharp downfall. Nevertheless, Brazil did not suffer the Argentinian drama of two years later, with the financial collapse of the neighbouring country. Foreign policy, on the other hand, was experiencing moments of uncertainty, since it was still attached to globalisation, contrary to a six-decade-old autonomist diplomatic tradition that predominated almost continuously from I930 to I990. Soon after, the world witnessed the terrorist attacks of September II, 200I, and the affirmation of the anti-terrorist security agenda towards the Middle East and Central Asia. Meanwhile, in the opposite direction, Latin America experienced the "pink tide" of social-democratic or popular-autonomist governments.

An unprecedented moment of international projection for Brazil, which, however, was not sustainable. The 2008 subprime crisis, which began in the United States, soon hit the Eurozone and the world economy. At the same time, the United States sought to withdraw from conflicts in the Middle East, leaving in place a series of not very solid local alliances. The scene for the "Arab Spring" was set and its shock waves would spread across the Mediterranean, Africa and West Asia. At that moment, a process of reversion of the previous trends began, with the wearing of social democratic regimes in Latin America, a movement that culminated in the election of Donald Trump in the United States. The logic of his administration is embedded in the unilateral diplomatic tradition of the Republican Party, with a business bias. Besides representing the very heart of the world system, the United States constitutes a National State with its own problems and needs, in parallel with migratory, climatic and social crises.

During these 20 years, we have sought to understand the underlying logic of ongoing international processes, and hope to have helped and assisted all those who attempt to analyse the international relations in a realistic way, rather than ideologically or prescriptively. This position is particularly important considering the disconcerting and perplexing moment endured by the Brazilian foreign policy. Different historical times seem to overlap, in a 
structurally contradictory project in which the harsh reality reveals itself in a surrealistic setting.

\section{ANNEX \\ (Titles available in Portuguese or Spanish only)}

\section{International Relations and Integration Series (1998-2008)}

The Foreign Policy of the Brazilian Military Regime (I964-I985), by Paulo Visentini; International Relations and Brazilian Foreign Policy, by Paulo Roberto de Almeida; Mercosur and its Regional and International Context, by Jacques Ginesta; Five Hundred Years in the Periphery, by Samuel Pinheiro Guimarães; Rethinking International Relations, by Fred Halliday; China and Southeast Asia, by Paulo Antônio Pereira Pinto; Foreign Policy of the United States of America, by Cristina Soreanu Pecequilo; From Import to Export Substitution, by Heloísa Silva; Brazil and the League of Nations, by Eugenio Vargas Garcia; Regional Integration Processes and International Cooperation since 1989, by Marianne Wiesebron and Richard T. Griffiths (Eds.). In partnership with FUNAG/MRE: Brazil and the People's Republic of China (1974-2001), by Danielly Ramos Becard; Diplomacy and Religion: the relations between the Holy See and the People's Republic of China (1949-2005), by Anna Carletti.

\section{International Studies Series (2003-2009)}

Diplomacy of National Interest: the foreign policy of the Médici Administration, by Cíntia Souto; The Foreign Policy of the Sarney Administration (1985-1990), by Analúcia Danilevicz Pereira; Changes in Brazilian Foreign Policy during the 1980s: a newly industrialised medium power, by Ricardo Sennes; Brazilian Diplomacy between Security and Development: the foreign policy of the Castelo Branco administration (1964-1967), by André Silva; The Kosovo War, NATO, and the Concept of "Humanitarian Intervention", by Paulo Roberto Caminha de Castilhos França; The Arctic and Antarctica in International Relations, by Myriam Colacrai; The Foreign Policy of the Itamar Franco Administration (1992-1994), by Ney Canani; Taiwan: a formidable future for the island?, by Paulo Antônio Pereira Pinto; A New American Hegemony or Multipolarity? Power poles of the International System, by Paulo Visentini and Marianne Wiesebron (Eds.).; German Unification in the Context of German-Soviet Relations (1985-1990), by Elmir Flach; South America: economics and regional integration politics, by Marco Aurélio Chaves Cepik (Ed.).; Brazil-India Relations (1991-2006), by Maíra Baé Baladão Vieira. 


\section{South-African Series (2007-2011) (in partnership with FUNAG/ MRE)}

South Africa and IBSA: human security, by Francis Kornegay and Jabulani Dada (Eds.); Brazil and South Africa (1918-2000), by Pio Penna Filho; A Short History of Africa, by Paulo F. Visentini, Luiz Dario Ribeiro and Analúcia Danilevicz Pereira; South Africa: history, state and society, by Paulo Visentini and Analúcia Danilevicz Pereira (Eds.); South Africa: the transnational activism network against Apartheid, by Pablo Saturnino Braga.

\section{Strategy, Defence and International Relations Series (2013-)}

The North-American Independence: war, revolution and logistics, by Érico Esteves Duarte; Revolutions and Marxist Regimes: ruptures, experiences and international impact, by Paulo F. Visentini, A. D. Pereira, J. M. Martins, L. D. Ribeiro and L. G. Gröhmann; Constants and Variations: Brazil's multilateral diplomacy, by Gelson Fonseca Jr.; Environmentalism and Indigenism: Roraima as a laboratory for international regimes, by Getúlio de Souza Cruz; African (In)Security and its Importance for Brazilian National Defence, by Paulo Fagundes Visentini, Eduardo Glaser Migon and Analúcia Danilevicz Pereira (Eds.); The Foreign Policy Guide of African States, by Paulo Visentini and NERINT/CEBRAFRICA; Defence Diplomacy in International Politics, by Antônio Ruy de Almeida Silva. 